\title{
Keterlibatan Warga Negara Muda \\ Dalam Gerakan Kewarganegaraan Ekologis Untuk Mewujudkan Pembangunan \\ Berkelanjutan Berwawasan Lingkungan
}

\author{
Leha Silfiana, Samsuri
}

Universitas Negeri Yogyakarta

lehasilfiana.2018@student.uny.ac.id.| samsuri@uny.ac.id

\begin{abstract}
Young citizens have a strategic role in the movement to care for the environment. They are considered as guardian angels for the environment from the cruel economic development and development. Their involvement in the environmental movement will have a major impact on environmental sustainability. The ecological citizenship movement can be a bridge to bring young citizens to the success of environmentally sustainable development. The ecological citizenship movement is a social activity that focuses its activities on saving the environment from human selfish actions. The purpose of this study is to analyze the importance of the involvement of young citizens in the ecological citizenship movement to realize sustainable development with an environmental perspective. This research uses a literature study approach. Data sources were obtained from the results of reviews of journal articles or books related to ecological citizenship, sustainable development, and case studies on the involvement of young citizens in environmental management. This article consists of three discussions that fit the focus of this research. First, it outlines a description of the ecological citizenship movement. Second, it presents the results of an analysis of the forms of involvement of young citizens in the ecological citizenship movement from various case studies. Third, present the results of an analysis of the importance of the involvement of young citizens in environmentally sustainable development. Based on the results of the study it can be concluded that the involvement of young citizens in the ecological citizenship movement and sustainable development programs is very important, because they are the actors responsible for environmental sustainability and development in the future.
\end{abstract}

\section{KEYWORDS Citizenship | Ecological | Development | Sustainable | Environment}

\section{PENDAHULUAN}

Seiring dengan semakin tuanya usia planet bumi, jumlah dan kualitas sumber daya alam yang ada di dalamnya juga mengalami penurunan. Hal ini akan mempengaruhi keberlangsungan hidup manusia terutama bagi mereka yang menggantungkan hidupnya pada jasa sumber daya alam. Saat ini manusia memanfaatkan sumber daya alam sekitar $50 \%$ lebih banyak dibandingkan dengan 30 tahun lalu, yakni 60 triliun ton bahan mentah tiap tahunnya dan jumlah ini akan terus bertam- bah sampai 100 triliun ton di tahun 2030 (SERI, GLOBAL 2000; Friends of the Earth Europe 2009). Konsumsi jasa sumber daya alam paling banyak ditemukan di negara-negara maju seperti Amerika Serikat, Eropa, dan Afrika. Tiap-tiap orang di negara maju rata-rata mengonsumsi sumber daya alam antara $10 \mathrm{~kg}$ sampai 90kg per hari. Jika gaya hidup orang Amerika Serikat diadopsi oleh seluruh manusia di dunia, maka dibutuhkan 4 planet bumi untuk memenuhi tuntutan kebutuhan manusia atas sum- 
ber daya alam (WWF 2012).

Negara Indonesia juga mulai menghadapi banyak masalah serius mengenai buruknya pengelolaan lingkungan hidup yang mengakibatkan terjadinya deforestasi, polusi air, polusi udara, dan punahnya keanekaragaman hayati. Maraknya bencana alam dan perubahan suhu udara yang ekstrim juga menjadi pertanda semakin buruknya kondisi lingkungan Indonesia. Banjir menjadi bencana alam yang tidak pernah absen di beberapa wilayah Indonesia khususnya wilayah perkotaan. Berdasarkan data Badan Pusat Statistik (BPS) tiap tahun bencana alam banjir mengalami peningkatan. Pada tahun 2016-2017 terjadi 1.805 kejadian banjir yang menyebabkan hilangnya korban sebanyak 433 jiwa (BPS 2018).

Sampah plastik masih menjadi salah satu penyebab utama terjadinya banjir di Indonesia. Dalam riset yang dilakukan oleh Jambeck et al (2015) terhadap 192 negara, ditemukan bahwa Indonesia menyumbang sebanyak 3,22 juta metrik ton (millions of metric tons/MMT) limbah plastik. Penelitian lebih spesifik dilakukan oleh Lamb et al (2018) yang berjudul Plastic Waste Associated with Disease on Coral Reefs. Riset ini menunjukkan bahwa sampah plastik paling banyak ditemukan di Indonesia, yakni 25,6 bagian per $100 \mathrm{~m}^{2}$ terumbu karang di lautan. Peristiwa terdamparnya paus sperma di perairan laut Wakatobi yang terjadi pada bulan November 2018 menjadi salah satu bukti bahwa pengelolaan sampah plastik belum berjalan maksimal di Indonesia. Ketika perut paus sperma tersebut dibuka ditemukan berbagai macam sampah plastik yang beratnya mencapai $5,9 \mathrm{~kg}$. Berdasarkan data yang dihimpun dari artikel Detik.com, sampah plastik yang memenuhi perut paus berupa tali rafia, gelas plastik, sandal, kantong plastik dan karung plastik (Medistiara 2018).

Perkembangan dalam bidang ekonomi terutama dalam bisnis kuliner juga menjadi salah satu penyebab meningkatnya volume sampah di Indonesia. Perubahan pola konsumsi warga negara Indonesia yang lebih senang mengonsumsi makanan cepat saji menimbulkan dampak buruk bagi lingkungan. Umumnya restoran cepat saji menggunakan wadah tempat makan, gelas, dan sendok garpu yang hanya sekali pakai. Pola konsumsi semacam ini sangat memengaruhi penambahan timbunan sampah (BPS 2018). Selain itu, maraknya aplikasi-aplikasi belanja online semakin mempercepat perubahan pola hidup konsumtif warga negara Indonesia. Beberapa aplikasi belanja online yang menawarkan berbagai diskon dan promo membuat warga negara semakin rajin untuk melakukan transaksi dan membeli barang-barang yang tidak mereka butuhkan. Tindakan-tindakan warga negara yang tidak terkontrol menjadi akar dari masalah lingkungan. Sikap egois pada diri warga negara membuat mereka tidak lagi memikirkan dampak buruk dari tindakannya terhadap kelestarian alam dan lingkungan.

Peristiwa kabut asap di daerah Sumatera dan Kalimantan yang terjadi pada tahun 2015 juga menjadi salah bentuk keegoisan warga negara. Pembakaran hutan merupakan tindakan yang tidak sesuai dengan nilai-nilai ramah lingkungan. Selain dapat merusak ekosistem hutan, proses pembakaran juga akan menyebabkan terjadinya polusi udara. Kabut asap yang dihasilkan dari pembakaran hutan di Kalimantan tidak hanya mengganggu warga negara lokal, akan tetapi juga berdampak bagi warga negara di negara lain, misalnya di Malaysia. Tindakan tersebut tentunya tidak sesuai dengan Undang-Undang Nomor 32 Tahun 2009 tentang Perlindungan dan Pengelolaan Lingkungan Hidup Pasal 66 yang menyatakan "setiap orang mempunyai hak yang sama atas lingkungan hidup yang sehat dan baik".

Warga negara perlu mengurangi sikap egois dan gaya konsumtif yang berlebihan untuk mencegah kerusakan alam dan lingkungan. Tingginya kebutuhan akan jasa lingkungan dan keterbatasan jumlah sumber daya alam serta menurunnya kualitas sumber daya alam mem- 
buat warga negara harus bertanggung jawab terhadap tindakan mereka (Widjajanti 2014). Meskipun Indonesia memiliki sejumlah undang-undang tentang lingkungan, namun belum mampu membuat warga negara Indonesia sadar akan pentingnya menjaga kelestarian lingkungan (Hsu and Perry 2014). Dalam hal ini perlu disusun program-program pro-lingkungan yang digerakkan oleh warga negara sendiri untuk mencegah adanya kejahatan ekologi (Prasetiyo and Budimansyah 2016). Gerakan yang dapat dilakukan oleh warga negara adalah gerakan kewarganegaraan ekologis. Gerakan ini identik dengan kesadaran warga negara akan tanggung jawab mereka terhadap kelestarian lingkungan dengan menerapkan gaya hidup yang ramah lingkungan (Dobson 2007).

Warga negara muda menjadi salah satu tokoh yang dapat diandalkan untuk menjalankan gerakan kewarganegaraan ekologis. Kreativitas, semangat, dan ide-ide inovatif yang mereka miliki mampu memengaruhi warga negara lain untuk ikut serta dalam gerakan kewarganegaraan ekologis. Salah satu warga negara muda yang berhasil menjadi aktivis lingkungan adalah Greta Thunberg yang masih berusia 16 tahun (Welle 2019). Gadis muda ini menyuarakan gerakan mogok sekolah demi iklim. Aksi yang ia lakukan didasari atas keprihatinan terhadap lambannya penanganan peristiwa perubahan iklim. Kegigihannya membawakan hasil yang memuaskan. Selain mendapatkan nobel perdamaian, berkat gerakan yang ia lakukan saat ini kampanye mengenai perubahan iklim direncanakan akan berlangsung dilebih dari 2000 kota pada 123 negara (Welle 2019).

Indonesia adalah negara yang akan mengalami puncak bonus demografi pada tahun 2025-2030. Bonus demografi menunjukkan jumlah warga negara usia produktif lebih banyak dibanding dengan warga negara usia tidak produktif. Pada tahun 2018 warga negara muda mengisi seperempat dari jumlah seluruh masyarakat di Indonesia yaitu sekitar 63,82 juta jiwa (BPS 2018). Fenomena ini akan menjadi bomerang yang akan mempersulit kehidupan masyarakat Indonesia jika kualitas pemuda tidak dipersiapkan dengan baik.

Berbeda dengan banyak negara maju di kawasan Amerika, Indonesia memiliki kekayaan alam yang sangat melimpah. Hal ini harus dapat dimanfaatkan oleh generasi muda agar mampu membawa Indonesia bersaing dengan negara-negara lain. Pemuda harus mampu menyeimbangkan antara pembangunan dan pengelolaan lingkungan. Pengintegrasian nilainilai ramah lingkungan dalam sendi pembangunan akan memberikan dampak positif dalam kehidupan manusia di masa depan. Konsep pembangunan seperti itu disebut dengan konsep pembangunan berkelanjutan (suistainable development). Pembangunan berkelanjutan menggambarkan perlindungan terhadap lingkungan dari pesatnya pertumbuhan ekonomi. Wacana ini membingkai masalah lingkungan sebagai upaya untuk mencari keseimbangan yang tepat antara perlindungan lingkungan, pertumbuhan ekonomi, dan keadilan sosial lintas ruang dan waktu (Hysing and Olsson 2018).

Malapetaka lingkungan terjadi karena adanya ketidakseimbangan antara kebutuhan manusia dengan ketersediaan sumber daya alam. Pola konsumsi masyarakat yang semakin berlebihan serta fenomena bonus demografi yang akan terjadi di masa depan menjadi tantangan berat bagi generasi muda di Indonesia. Sehingga keterlibatan pemuda dalam mengatasi persoalan lingkungan hidup merupakan agenda yang harus terealisasikan.

Keterlibatan warga negara menjadi target penting dalam penelitian di pertengahan abad 21 (Laitenen 2018). Namun, masih sedikit penelitian yang menyoroti keterlibatan pemuda sebagai warga negara yang memiliki hak dan kewajiban terhadap pengelolaan lingkungan hidup. Padahal kesadaran warga negara muda terhadap pentingnya menjaga dan melestarikan lingkungan merupakan salah satu pondasi untuk mewujudkan pembangunan berkelanjutan. 
Oleh karena itu, fokus penelitian dalam tulisan ini adalah bagaimana pentingnya keterlibatan warga negara muda dalam gerakan kewarganegaraan ekologis untuk mewujudkan pembangunan berkelanjutan berwawasan lingkungan.

Tulisan ini berpendapat bahwa memperkuat kesadaran lingkungan pada diri warga negara adalah pondasi untuk mewujudkan pembangunan berkelanjutan. Sumber daya manusia yang memiliki posisi strategis sebagai aktor lingkungan dan pembangunan berkelanjutan adalah warga negara muda. Salah satu langkah untuk memperkuat posisi dan peran warga negara muda dalam pengelolaan lingkungan dan pembangunan berkelanjutan adalah dengan melibatkan mereka dalam gerakan kewarganegaraan ekologis. Hal ini penting dilakukan untuk mengantisipasi terjadinya degradasi lingkungan akibat pesatnya perkembangan pembangunan yang tidak diimbangi dengan kesadaran akan pentingnya mengelola lingkungan yang baik.

Argumen di atas akan dibuktikan melalui hasil kajian dalam penelitian ini. Untuk itu, tulisan ini akan dibagi dalam beberapa bagian. Pertama, tulisan ini akan menguraikan mengenai konsep kewarganegaraan ekologis. Kedua, tulisan ini akan memaparkan hasil analisis dari berbagai studi kasus tentang bentuk keterlibatan warga negara muda dalam gerakan kewarganegaraan ekologis. Ketiga, tulisan ini akan menguraikan pentingnya keterlibatan warga negara muda dalam pembangunan berkelanjutan berwawasan lingkungan. Pada akhir tulisan akan dipaparkan kesimpulan yang menjelaskan kontruksi teori dari hasil temuan dalam penelitian.

\section{METODE PENELITIAN}

Desain penelitian dalam tulisan ini menggunakan studi kepustakaan (library research). Studi kepustakaan dilakukan dengan cara melakukan telaah terhadap berbagai sumber kepustakaan seperti buku, dokumen, jurnal, majalah, dan lain-lain (Mahmud 2011). Sumber pustaka yang akan dikaji dalam penelitian ini disesuaikan dengan fokus penelitian yaitu tentang gerakan kewarganegaraan ekologis, pembangunan berkelanjutan dan studi kasus tentang keterlibatan warga negara muda dalam pengelolaan lingkungan. Temuan dari berbagai sumber pustaka akan dikelompokkan sesuai dengan fokus pembahasan. Setelah data dikelompokkan kemudian data akan dianalisis dengan cara membandingkan, memilih, dan menggabungkan berbagai sumber data sehingga membentuk sebuah tulisan yang utuh dan mudah dipahami.

\section{TEMUAN DAN ANALISIS}

Gerakan Kewarganegaraan Ekologis

Manusia adalah aktor yang paling bertanggung jawab terhadap lingkungannya (Iskandar 2009). Tindakan yang dipilih oleh manusia memberikan dampak yang cukup besar terhadap kelestarian alam dan lingkungan. Oleh karena itu, beberapa aturan atau kebijakan dikeluarkan untuk membatasi perilaku manusia terhadap lingkungan. Manusia harus menjadi anggota dalam suatu negara sesuai dengan perundang-undangan yang berlaku di negara tersebut agar dapat menjalankan hak dan kewajibannya terhadap alam dan lingkungan. Salah satu bentuk keanggotaannya adalah memiliki status kewarganegaraan.

Menurut Winter (2013) keseimbangan sosial (socio-proporsionalitas) terutama akan melindungi hak-hak dasar warga negara terhadap instruksi pemerintah, sementara keseimbangan ekologis akan melindungi alam dari instruksi yang dilakukan oleh masyarakat (termasuk pemerintah yang mengonsumsi alam). Secara sederhana dapat dikatakan bahwa menjaga keseimbangan alam merupakan kewajiban bagi masyarakat, sehingga masyarakat bukan hanya memiliki hak untuk mengeksplorasi kekayaan alam namun juga harus mampu melestarikannya.

Konseptualisasi kewarganegaraan baru-baru ini memunculkan gagasan kewarganegaraan ekologis. Kewarganegaraan ekologis merupakan konsep yang diperkenalkan sejak tahun 
1990-an dalam dokumen kebijakan, akademisi, dan kampanye kelembagaan (Melo-Escrihela 2008:114). Pada dasarnya kewarganegaraan ekologis berkaitan dengan kontrol internal yang kuat dalam diri warga negara, di mana mereka tidak hanya memiliki nilai-nilai ekologis tetapi juga menerjemahkan nilai-nilai itu ke dalam perilaku peduli lingkungan, baik dari ruang publik maupun dalam kehidupan pribadi mereka di rumah (Dobson 2007). Kewarganegaraan ekologis menyajikan kisah tentang bagaimana individu (warga) harus menjalani kehidupan mereka dengan mengurangi dampak buruk bagi lingkungan mereka (Wolf, Brown, and Conway 2009). Individu yang sejalan dengan kewarganegaraan ekologis cenderung memiliki perilaku yang ramah lingkungan dibanding dengan individu lainnya (Dobson 2007). Mereka yang termasuk dalam warga negara ekologis akan mengutamakan tanggung jawab terhadap lingkungan daripada menuntut hak untuk mengeksplorasi lingkungan. Jadi, pendekatan kewarganegaraan ekologis didukung oleh tanggung jawab moral dan etika yang dihasilkan dari lingkungannya, membutuhkan internalisasi nilai-nilai dan aturan ekologis, dan pendekatan ini lebih bertumpu pada kontrol diri dan kontrol informal daripada kontrol normatif (Biagi and Ferro 2011).

Membentuk perilaku yang berhubungan dengan sikap peduli lingkungan tidak dapat dilakukan dengan mudah atau dengan sesuka hati. Dibutuhkan suatu tindakan khusus, fasilitas dan pelibatan serta pengorbanan di luar kapasitas individu (Martinsson and Lundqvist 2010:523). Dalam hal ini pemerintah dapat bekerjasama dengan masyarakat untuk membentuk program-program peduli lingkungan. Kerjasama ini dapat berupa sosialisasi peduli lingkungan, pembangunan fasilitas publik yang ramah lingkungan, membuat kebijakan-kebijakan yang pro-lingkungan, memperbanyak jumlah bank sampah dan lain-lain. Program KOTAKU yang dilaksanakan oleh pemerintah Kota Sukoharjo dapat menjadi salah satu contoh bentuk tindakan khusus dalam pembentukan kewarganegaraan ekologis. Program tersebut direncanakan secara terpadu dengan melaksanakan dialog, sosialisasi, dan pelatihan kepada masyarakat Kota Sukoharjo (Nugroho 2017). Tujuannya adalah mengembangkan gerakan kewarganegaraan ekologis pada diri masyarakat. Dalam gerakan kewarganegaraan ekologis, keterlibatan pemerintah memang sangat penting.

Dalam tataran masyarakat - dalam konteks ini adalah warga negara memiliki karakteristik yang berbeda-beda dalam menunjukkan kepedulian mereka terhadap lingkungan. Martinsson and Lundqvist (2010) mengatakan bahwa terdapat empat kategori praktik dan sikap ekologis yang biasanya ditunjukkan oleh warga negara. Pertama believers, menunjukkan adanya konsistensi antara sikap dan praktik ekologis. Dalam hal ini individu memiliki sikap yang positif terhadap lingkungan dan menunjukkan praktik yang bertanggung jawab secara ekologis. Kedua kategori diehards, warga negara dalam kategori ini biasanya bertindak tanpa memperhatikan tanda-tanda dampak lingkungan yang merugikan. Ketiga kategori hypocrites, warga negara dalam kategori ini termasuk orang yang munafik, karena mereka hanya menunjukkan sikap dan praktik ekologis pada waktu-waktu tertentu dan ketika di depan banyak orang, akan tetapi tidak menjalankan praktik ekologis dalam kehidupan sehari-hari. Keempat kategori coverts, sikap kewarganegaraan dalam kategori ini hanya berupa motivasi saja. Mereka yang termasuk kategori coverts tidak menunjukkan sikap ekologisnya secara nyata. Mereka tahu bahwa menjalankan kehidupan ramah lingkungan itu penting namun mereka masih kesulitan untuk menjalankannya.

Berpedoman pada kategori sikap dan praktik ekologis di atas dapat dikatakan bahwa ketika dalam satu negara mayoritas warga negaranya termasuk dalam kategori believers maka di negara tersebut tingkat permasalahan lingkungan akan sangat rendah. Sebaliknya jika mayoritas warga negara dalam satu negara termasuk dalam kategori diehards maka tingkat 
permasalahan lingkungan akan sangat tinggi. Untuk dapat mencapai pembangunan berkelanjutan maka perlu memperkuat karakteristik warga negara hyprocrites dan coverts agar mereka mampu meningkatkan karakteristik tersebut menjadi karakteristik believers.

Pembuatan kebijakan yang mengatur mengenai hak dan kewajiban warga negara terhadap lingkungan tidak serta-merta mampu membentuk kewarganegaraan ekologis dengan cepat dan sempurna meski disertai dengan sangsi yang tegas. Kesadaran diri warga negara terutama warga negara muda sangat diperlukan dalam mendukung keberhasilan gerakan kewarganegaraan ekologis. Warga negara muda diasumsikan sebagai agen perubahan yang mampu memberikan kontribusi besar dalam menekan angka permasalahan lingkungan melalui perubahan kebiasaan atau gaya hidup yang lebih ramah lingkungan.

Bentuk Keterlibatan Warga Negara Muda dalam Gerakan Kewarganegaraan Ekologis

Permasalahan mengenai lingkungan tidak mudah untuk diselesaikan. Dibutuhkan keterlibatan dari berbagai pihak untuk menguraikan permasalahan ini. Sampai saat ini, pemecahan masalah lingkungan masih dibebankan kepada pemerintah. Masyarakat hanya menjalankan apa yang diputuskan oleh pemerintah. Hal ini membuat pemerintah menerapkan beberapa kebijakan yang justru merugikan masyatakat dan lingkungan. Apabila melihat kondisi di wilayah Italia Utara, kebijakan-kebijakan yang dirumuskan oleh pemerintah lebih bersifat pro-rakyat karena adanya partisipasi dan keterlibatan masyarakat dalam pemecahan masalah. Sementara untuk wilayah Italia Selatan yang tidak memberikan akses kepada keterlibatan warga negara untuk ikut dalam proses pemerintahan, menghasilkan pemerintahan yang korup (Putnam 1992).

Berkaca dari pengalaman Italia, dapat dikatakan bahwa dalam penyelesaian masalah lingkungan yang terjadi suatu negara dibutuhkan keterlibatan dari warga negara. Dalam hal ini pemerintah juga harus memberikan kesempatan kepada warga negara untuk menyampaikan gagasan dan idenya untuk mengatasi permasalahan lingkungan. Pemerintah dapat memberikan kesempatan dan dukungan terutama terhadap warga negara muda. Gagasan dan ide inovatif biasanya akan muncul dari pemikiran anak-anak muda.

Keterlibatan warga negara muda dalam pengelolaan lingkungan menempati posisi yang penting (Tindangen 2017). Dalam mengembangkan kewarganegaraan ekologis, warga negara muda dapat berpartisipasi sebagai individu maupun sebagai anggota dari komunitas atau organisasi yang bergerak dalam bidang lingkungan. Tugas utama warga negara muda sebagai individu dalam gerakan kewarganegaraan ekologis adalah melindungi lingkungan. Warga negara muda harus mampu mengendalikan diri untuk mengurangi penggunaan sumber daya alam yang berlebihan guna menghindari dampak kerusakan lingkungan (Latta 2007:380).

Bentuk keterlibatan warga negara muda dalam gerakan kewarganegaraan ekologis sebagai seorang individu dapat dilakukan dalam kehidupan sehari-hari di lingkungan tempat tinggalnya. Dengan berkembangnya kemajuan teknologi bisa dipastikan setiap rumah memiliki berbagai macam alat elektronik yang menggunakan energi listrik sebagai sumber dayanya, seperti televisi, lampu, kipas angin, AC, pompa air, dan lain-lain. Untuk mengurangi efek buruk pada lingkungan, warga negara muda dapat melakukan serangkaian perilaku yang menunjukkan sikap ramah lingkungan, seperti aktivitas hemat energi dan hemat air yang dilakukan dengan cara memasang perangkat hemat energi dan hemat air (Bar, Shaw, and Gilg 2011). Hal lain yang dapat dilakukan oleh warga negara muda di lingkungan rumah adalah menyediakan 2 tempat sampah untuk memisahkan sampah yang dapat didaur ulang dan sampah yang tidak dapat didaur ulang. Tanpa disadari jenis sampah rumahan mendominasi jumlah volume sampah di tempat pembuangan sampah. 
Dengan memilah-milah sampah rumahan, maka akan sedikit mengurangi volume sampah di tempat pembuangan sampah. Warga negara muda dapat memanfaatkan sampah rumahan yang masih dapat didaur ulang untuk menjadi bahan-bahan kerajinan atau bisa menjualnya di tempat-tempat yang menjual barang-barang bekas. Sampah rumahan yang dapat didaur ulang misalnya plastik bekas makanan, kresek, botol air minum, botol minyak goreng, plastik detergen, dan lainlain. Proses daur ulang sampah tersebut akan menambah nilai ekonomis sampah dan menambah pendapatan dari warga negara muda. Ahli teori kewarganegaraan ekologis menganggap tindakan individu seperti mendaur ulang dan membeli barang ramah lingkungan sebagai tugas yang harus dilakukan oleh seorang warga negara (Kennedy 2011).

Warga negara muda sebagai individu juga memiliki tugas untuk mendukung program-program pro-lingkungan. Warga negara muda dapat berperan sebagai relawan dalam kegiatan-kegitan lingkungan. Melalui semangat dan pemikirannya, warga negara muda dapat mempengaruhi masyarakat dengan memberikan edukasi dalam program-program pro-lingkungan sehingga masyarakat terlatih dan terbiasa untuk mempraktikkan sikap ramah lingkungan. Hal tersebut dapat dilihat pada program Kampoeng Recycle di Jember. Salah satu strategi untuk memaksimalkan pembentukan kewarganegaraan ekologis di daerah tersebut adalah dengan melibatkan generasi muda baik mahasiswa maupun relawan dalam kegiatan Kampoeng Recycle (Jannah 2018).

Selain mendukung program lingkungan dengan menjadi relawan, warga negara muda juga dapat bergabung dengan komunitas-komunitas lingkungan sebagai langkah awal untuk memperkuat gerakan kewarganegaraan ekologis. Dengan mengikuti program-program yang ada pada komunitas lingkungan maka mereka akan semakin terampil dalam memilih tindakan-tindakan yang tidak merugikan lingkun- gan. Warga negara muda yang bergabung dalam suatu komunitas lingkungan akan memperkuat karakter peduli lingkungan untuk memperbaiki, mengurangi limbah dan kerusakan lingkungan (Gusmadi 2018).

Beberapa komunitas lingkungan di Kota Yogyakarta juga telah memberikan kontribusinya terhadap penguatan gerakan kewarganegaraan ekologis. Salah satunya komunitas Jogja Berkebun yang memiliki peran sebagai penggerak kepedulian lingkungan. Komunitas tersebut memberikan edukasi kepada anggotanya tentang tata cara mengolah lahan kebun yang ramah lingkungan, memadukan program lingkungan dengan budaya masyakat, menjalin kemitraan dengan masyarakat untuk memproduksi pangan dari hasil kebun, dan lain-lain (Swandana 2017).

Organisasi Greenpeace juga merupakan komunitas yang berkonsentrasi pada lingkungan. Kegiatan yang dilakukan untuk mengembangkan kewarganegaraan dengan cara memberikan kampanye tentang isu lingkungan, seperti Visit School, Earth Camp, Movie Screening, Basic Training, Training Social Media, Moratorium Hutan, Protect Paradise, Global Day Action, Bersih Pantai, Hari Peduli Sampah Nasional, Solarizing Borobudur, Tolak PLTU Batang, Buru Baru Festival, Hari Air sedunia (Putra 2016). Fokus sasaran dari kegiatan yang dilakukan oleh organisasi ini tidak hanya masyarakat saja akan tetapi juga siswa/siswi di sekolah.

Berdasarkan teori politik hijau, daerah perkotaan merupakan ruang penting untuk penanaman sikap kewarganegaraan ekologis (Travalline and Hunold 2010). Hal ini menjadi keuntungan bagi warga negara muda yang bertempat tinggal di wilayah perkotaan. Mereka dapat berpartisipasi untuk mengelola lingkungan perkotaan mereka. Misalnya, Kota Bandung memiliki komunitas anak muda yang peduli lingkungan di mana kegiatan yang dilakukan bertujuan untuk memasyarakatkan pertanian kota (urban agriculture) sebagai gaya hidup 
peduli lingkungan. Komunitas ini disebut dengan organisasi Bandung Berkebun. Komunitas ini memiliki beberapa program yang mampu membentuk kewarganegaraan ekologis, seperti urban farming, school urban farming, street urban farming, dan campus urban farming.

Keterlibatan aktif warga negara muda dalam mengembangkan gerakan kewarganegaraan ekologis sangatlah penting untuk menjaga kelangsungan hidup seluruh makhluk hidup. Warga negara muda sebagai calon generasi penerus bangsa harus mampu menjaga lingkungannya agar dapat dinikmati oleh generasi-generasi setelahnya. Selain itu, pengembangan kewarganegaraan ekologis juga penting untuk menunjang keberhasilan pembangunan berkelanjutan yang berwawasan lingkungan.

Pentingnya Keterlibatan Warga Negara Muda dalam Pembangunan Berkelanjutan

Pembangunan dan lingkungan menjadi dua isu yang menjadi perbincangan hangat di pertengahan abad ke-21. Banyak laporan kebijakan baik nasional maupun internasional yang menekankan pentingnya hubungan antara pembangunan dan lingkungan. Pada tahun 1987, Komisi Bruntland menerbitkan laporan "Our Common Future" yang berisi tentang upaya menghubungkan isu-isu pembangunan ekonomi dan stabilitas lingkungan yang kemudian dikatakan sebagai program pembangunan berkelanjutan. Dalam laporan ini pembangunan berkelanjutan didefinisikan sebagai pembangunan yang memenuhi kebutuhan saat ini tanpa mengurangi kemampuan generasi mendatang untuk memenuhi kebutuhan mereka sendiri (WCED 1987). Berdasarkan laporan tersebut dapat dikatakan bahwa pembangunan berkelanjutan memiliki tiga tujuan utama yaitu menjaga kelestarian ekologis jangka panjang, memuaskan kebutuhan dasar manusia, dan mempromosikan kesetaraan antar-generasi ke generasi berikutnya.

Tjokrowinoto (2012:12) mengungkapkan bahwa dalam pembangunan berkelanjutan kaum environmentalist menghendaki adanya interaksi antara manusia dan lingkungan dalam pelaksanaan pembangunan berkelanjutan. Selain itu, pembangunan juga harus memperhatikan efek yang diberikan kepada bumi atau world system pada jangka waktu yang panjang. Hal tersebut didasari atas keprihatinan terhadap konsekuensi jangka panjang pada kegiatan pembangunan yang melakukan eksploitasi terhadap sumber daya alam. Mereka menyadari bahwa ada batas-batas tertentu dalam memanfaatkan sumber daya alam agar mampu dipergunakan untuk saat ini maupun di masa yang akan datang.

Dalam pembangunan berkelanjutan terdapat dua konsep yang memiliki fokus yang berbeda yaitu pembangunan dan berkelanjutan. Pembangunan lebih berorietansi pada manusia, ekonomi, dan masyarakat (Kates, Parris, and Leiserowitz 2005). Perlu disadari bahwa pembangunan tidak hanya berhenti dalam satu lingkungan saja, akan tetapi memengaruhi lingkungan lain bahkan mampu memberikan efek pada wilayah negara, sehingga penting untuk membangun konsep warga negara yang peduli lingkungan (kewarganegaraan ekologis). Warga negara yang melek ekologis memberikan keuntungan bagi keberhasilan pembangunan jangka panjang.

Sementara konsep berkelanjutan berkaitan dengan tiga hal yaitu alam, lingkungan hidup, dan budaya masyarakat (Kates, Parris, and Leiserowitz 2005). Pembangunan yang tidak memperhatikan efek jangka panjang akan mengancam ketiga hal di atas. Alam dan lingkungan hidup merupakan sumber layanan untuk mendukung kehidupan manusia. Keberadaan jasa ekosistem alam memberikan manfaat yang banyak bagi kehidupan manusia, seperti penyediaan pangan dan sumber mata air. Selain itu, terdapat hubungan paralel antara alam, lingkungan hidup dan pelestarian budaya. Masyarakat memanfaatkan alam dan lingkungan hidup untuk mempertahankan mata pencaharian, suku/ kelompok, dan tempat tinggal komunitas-komunitas masyarakat. 
Pembangunan berkelanjutan merupakan program yang sangat penting untuk melindungi kehidupan manusia di masa yang akan datang. Namun, kenyataannya banyak tindakan-tindakan manusia yang tidak sesuai dengan prinsip pembangunan berkelanjutan. Manusia lebih menghargai alam karena nilai-nilai intrinsik yang terkandung di dalamnya yang dapat memberikan keuntungan bagi peningkatan perekonomian. Beberapa keputusan diambil tanpa memikirkan efek jangka panjang terhadap keberlangsungan lingkungan dan alam, seperti reklamasi teluk, penggundulan hutan untuk hotel atau penginapan, penutupan lahan sawah untuk pembangunan pabrik dan lain-lain. Proses pembangunan seperti ini dapat dengan mudah ditemui di lingkungan pedesaan dan pesisir pantai. Salah satu penyebabnya adalah latar belakang ekonomi dan rendahnya pemahaman masyarakat terhadap dampak perusakan lingkungan hidup di masa yang akan datang (Karim 2017).

Agenda 2030 untuk pembangunan berkelanjutan mempromosikan transisi ke ekonomi hijau melalui upaya kolektif (Sanneh 2018). Penghijauan memiliki potensi yang besar untuk mengubah wajah bumi saat ini. Negara-negara berkembang seperti Indonesia memiliki kesempatan untuk menerapkan sistem ekonomi hijau guna mengurangi dampak ekonomi dan sosial dari perubahan iklim. Indonesia adalah negara dengan banyak sumber daya alam yang memiliki potensi degradasi lingkungan. Saat ini potensi itu belum begitu dirasakan oleh seluruh lapisan masyarakat. Namun, degradasi lingkungan mulai banyak dirasakan oleh masyarakat pedesaan yang mulai kehilangan lahan sawah mereka untuk pembangunan pabrik maupun jalan tol. Tantangan Indonesia untuk meningkatkan pembangunan berkelanjutan hanya akan meningkat di masa depan, karena terjadinya perubahan iklim yang akan memperburuk masalah lingkungan dan memunculkan konflik sosial atas sumber daya. Semakin sempitnya lahan akan membuat masyarakat saling berebut untuk memperoleh sumber daya alam.
Selain itu, peristiwa bonus demografi yang dialami Indonesia juga menjadi indikator bahwa dalam waktu dekat pembangunan di Indonesia akan terjadi dengan sangat pesat. Jika program pembangunan tidak disusun secara matang maka akan terjadi kekacauan yang disebabkan oleh ketidakseimbangan antara pembangunan dan lingkungan. Hal ini akan mengancam keberlangsungan hidup warga negara muda di masa yang akan datang. Salah satu perencanaan yang mendesak untuk program pembangunan berkelanjutan adalah penguatan sumber daya manusia terutama warga negara muda untuk memiliki kesadaraan terhadap pentingnya menjaga lingkungan.

Pemuda semakin diakui sebagai agen positif perubahan dalam proses pembangunan dan perdamaian, berbeda dengan gagasan luas tentang 'anak-anak dan remaja sebagai korban' atau 'pemuda sebagai masalah' (Felice and Wisler 2007). Mereka dianggap sebagai pemain dan mitra penting dalam pembangunan sebagaimana diungkapkan dalam beberapa pernyataan dan laporan pemerintah, organisasi antar-pemerintah internasional, dan organisasi non-pemerintah. Pernyataan-pernyataan ini merujuk terutama pada pentingnya kaum muda sebagai kelompok sasaran mengingat bahwa dibanyak masyarakat mereka mewakili sebagian besar populasi dan harapan diletakkan pada mereka karena mereka yang akan melanjutkan kehidupan di masa depan (Felice and Solheim 2011).

Adanya keterlibatan warga negara muda dalam rencana pembangunan berkelanjutan menjadi kekuatan besar bagi bangsa Indonesia karena di masa yang akan datang banyak negara di dunia akan memandang Indonesia sebagai mitra penting dalam proses pembangunan berkelanjutan (Hsu and Perry 2014). Hal tersebut didasarkan pada kenyataan bahwa warga negara muda atau generasi milenial menjadi konsumen yang mendominasi pasar saat ini (Syarif et al 2018). Oleh karena itu, warga negara muda perlu dipersiapkan untuk menghadapi tantangan 
pembangunan berkelanjutan pada masa ini dan masa yang akan datang.

Sesuai dengan agenda pembangunan berkelanjutan di tahun 2030 bahwa masyarakat harus memulai untuk menerapkan gaya hidup yang lebih ramah lingkungan dalam segala aspek terutama dalam segi ekonomi. Konsep gaya hidup ini umumnya digunakan sebagai sesuatu yang perlu diubah jika ingin mencapai pembangunan berkelanjutan (Jensen 2007). Apabila melihat gaya hidup warga negara muda saat ini cenderung tidak sesuai dengan prinsip gaya hidup yang ramah lingkungan. Banyak warga negara muda yang kecanduan dengan gaya hidup konsumtif dan hedonis. Mudahnya akses di berbagai situs jual beli online memudahkan mereka untuk menemukan barang-barang yang mereka butuhkan dengan cepat. Berbagai iklan yang menarik dan banyaknya promo yang ditawarkan membuat generasi milenial tidak berpikir dua kali untuk membelanjakan uangnya.

Pada dasarnya gaya hidup konsumtif tidak sejalan dengan gaya hidup ramah lingkungan. Dua gaya hidup ini ibarat dua sisi koin yang berlawanan. Warga negara muda harus dapat mengontrol diri untuk tidak mengikuti gaya hidup konsumtif demi menjaga kelestarian lingkungan hidup. Hal tersebut dicontohkan oleh orang-orang Tionghoa terutama penduduk lokal di kota Nanjing yang memiliki kesadaran kuat akan pentingnya pelestarian lingkungan dan bersedia mengurangi konsumsi mereka serta mengubah cara konsumsi mereka untuk melindungi lingkungan mereka dan mempertahankan gaya hidup sehat (Liu et al 2018). Penduduk Nanjing memilih untuk menabungkan uangnya daripada membelikannya untuk barang-barang sekali pakai.

Mengubah perilaku ‘buruk' menjadi perilaku 'baik' adalah proses linear untuk meningkatkan kesadaran pribadi akan tindakannya yang berdampak buruk pada lingkungan (Bar, Shaw, and Gilg 2011). Dalam proses perubahan maka seseorang akan mengalami masa transisi. Pada masa ini, seseorang masih kesulitan untuk meninggalkan gaya hidup lama dan mempertahankan gaya hidup baru. Oleh karena itu, untuk mengubah gaya hidup konsumtif menjadi gaya hidup ramah lingkungan maka warga negara muda dapat mengawalinya dengan melakukan tindakan meneliti sebelum membeli, pastikan barang yang akan dibeli menggunakan produk atau bahan baku yang ramah lingkungan. Biasanya produk yang ramah lingkungan memiliki tanda atau simbol recycle dalam kemasan produknya. Selain itu, warga negara muda dapat memilih produk yang tidak sekali pakai. Perubahan gaya hidup ini akan memberikan manfaat yang besar, bukan hanya pada diri pribadi namun juga untuk masyarakat secara global dan untuk mendukung pembangunan berkelanjutan berwawasan lingkungan.

Proses perubahan gaya hidup lama menjadi gaya hidup yang sejalan dengan konsep ramah lingkungan membutuhkan waktu dan pengorbanan dari warga negara muda. Gaya hidup yang ramah lingkungan akan memberikan efek positif pada kehidupan pribadi maupun kehidupan masyarakat secara luas. Warga negara muda sebagai pelindung lingkungan harus bisa memberikan contoh yang baik dalam pengelolaan lingkungan, karena pemanfaatan sumber daya alam tidak berhenti pada satu generasi akan tetapi individu-individu di bagian dunia manapun berhak mendapatkan kesempatan yang sama untuk memperoleh distribusi sumber daya alam.

\section{KESIMPULAN}

Warga negara muda adalah pewaris utama dari pembangunan dan lingkungan. Sangat penting mempersiapkan warga negara muda sedari dini untuk menghadapi tantangan degradasi lingkungan akibat pesatnya pembangunan di masa yang akan datang. Perlu adanya kerjasama dari berbagai pihak seperti pemerintah, masyarakat bahkan keluarga untuk memperkuat kesadaran peduli lingkungan pada diri warga negara muda melalui gerakan-gerakan kewarganegaraan ekologis. Gerakan kewarganega- 
raan ekologis adalah upaya yang dapat dilakukan untuk mengurangi dampak buruk tindakan manusia terhadap lingkungan. Gerakan ini menekankan pada kewajiban warga negara untuk menghargai dan melindungi lingkungan. Warga negara muda dapat memulai gerakan kewarganegaraan ekologis dengan meningkatkan kesadaran diri akan pentingnya berperilaku ramah lingkungan dengan cara membatasi diri untuk tidak melakukan eksploitasi terhadap alam dan lingkungan hidup.

Keterlibatan warga negara muda dalam gerakan kewarganegaraa ekologis dapat dilakukan dalam dua peran yaitu sebagai individu dan sebagai bagian dari organisasi lingkungan. Banyak cara yang dapat dilakukan oleh warga negara muda untuk mengaktualisasikan peran mereka dalam gerakan kewarganegaraan ekologis. Hal sederhana yang dapat dilakukan oleh warga negara muda adalah dengan mengurangi penggunaan kantong plastik, terbiasa membawa botol air minum sendiri, memilah sampah, menggunakan perlengkapan elektronik rumah tangga yang hemat energi, memastikan barang atau produk yang dibeli menggunakan bahan yang ramah lingkungan, dan lain-lain. Apabila tindakan-tindakan positif terhadap lingkungan dilakukan dengan konsisten maka tidak menutup kemungkinan generasi di masa depan juga akan dapat menikmati manfaat dari lingkungan.

\section{DAFTAR PUSTAKA}

Badan Pusat Statistik. 2018. Statistik Indonesia. Jakarta: Badan Pusat Statistik

Badan Pusat Statistik. 2018. Statistik Pemuda Indonesia. Jakarta: Badan Pusat Statistik

Barr, Stewart, Gareth Shaw and Andrew W. Gilg. 2011. "The Policy and Practice of 'Sustainable Lifestyles." Journal of Environmental Planning and Management 54(10):1331-1350.

Biagi, Marta and Mariano Ferro. 2011. "Ecological Citizenship and Social Representation of Water." SAGE Open 1(2):1-8.

Dobson, Andrew. 2007. "Environmental citizen- ship: towards sustainable development." Sustainable Development 15 (5): 276-285.

Felice, Celine Del and Andria Wisler. 2007. "The Unexplored Power and Potential of Youth as Peace-Builders." Journal of Peace Conflict \& Development (1):1-29.

Felice, Celine Del and Lilian Solheim. 2011. "Youth Organisations as Learning Organisations: Exploring Special Contributions and Challenges." Development in Practice 21(8): 1094-1108.

Gusmadi, Setiawan. 2018. "Keterlibatan Warga Negara (Civic Engagement) dalam Penguatan Karakter Peduli Lingkungan." Jurnal Pendidikan Ilmu-IImu Sosial 10(1): 31-37.

Hidayatullah, Syarif, Abdul Waris, Riezky Chris Devianti, Syafitrilliana Ratna Sari, Irawan Ardi Wibowo, and Pande Made PW. 2018. "Perilaku Generasi Milenial dalam Menggunakan Aplikasi Go-Food." Jurnal Manajemen \& Kewirausahaan 6(2): 240-249

Hsu, Sara and Nathan Perry. 2014. Lessons in Sustainable Development from Malaysia and Indonesia. New York: Palgrave Macmillan

Hysing, Erik and Jan Olsson. 2018. Green Inside Activism for Sustainable Development: Political Agency and Institutional Change. Switzerland: Springer

Iskandar. 2009. Metodologi Penelitian Pendidikan dan Sosial. Jakarta: Gaung Persada Press.

Jambeck, Jenna R., Roland Geyer, Chris Wilcox, Theodore R. Siegler, Miriam Perryman, Anthony Andrady, Ramani Narayan, and Kara Lavender Law. 2015. "Plastic Waste Inputs from Land Into the Ocean." Science 347(6223): 768-771

Jannah, Raudlatul. 2018. "Menciptakan Kewarganegaraan Ekologis di Era Digital Melalui Kampoeng Recycle Jember." Journal of Urban Sociology 1(2):14-26.

Jensen, Mikael. 2007. "Defining Lifestyle." Environmental Sciences 4(2): 63-73.

Karim, Abdul. 2017. "Mengembangkan Kesadaran Melestarikan Lingkungan Hidup berbasis Humanisme Pendidikan Agama." Edukasia: 
Jurnal Penelitian Pendidikan Islam 12(2):309330.

Kates, Robert W., Thomas M. Parris, and Anthony A. Leiserowitz. 2005. "What is Sustainable Development? Goals, Indicators, Values, and Practice." Environment 47(3):8-21.

Kennedy, Emily Huddart. 2011. "Rethinking ecological citizenship: the role of neighbourhood networks in cultural change." Environmental Politics 20(6):843-860.

Laitinen, Hanna. 2018. "Empowering New Agents of Civil Society or Fostering Good Citizens? Framing Youth Participation in Finnish Youth Organizations." Journal of Civil Society 14 (1): 1-18.

Lamb, Joleah B., Bette L. Willis, Evan A. Fiorenza, Courtney S. Couch, Robert Howard, Douglas N. Rader, James D. True, Lisa A. Kelly, Awaludinnoer Ahmad, Jamaluddin Jompa, and C. Drew Harvell. 2018. "Plastic Waste Associated with Disease on Coral Reefs." Science 359(6374): 460-462

Latta, P. Alex. 2007. "Localing Democratic Politics in Ecological Citizenship." Environmental Politics 16(3): 377-393.

Liu, Chen, Gill Valentine, Robert M. Vanderbeck, Katie McQuaid and Kristina Diprose. 2018. "Placing 'Sustainability' in Context: Narratives of Sustainable Consumption in Nanjing, China." Social \& Cultural Geography 1-18.

Kennedy, Emily Huddart. 2011. "Rethinking ecological citizenship: the role of neighbourhood networks in cultural change." Environmental Politics 20(6):843-860.

Mahmud. 2011. Metode Penelitian Pendidikan. Bandung: Pustaka Setia.

Martinsson, Johan and Lennart J. Lundqvist. 2010. "Ecological Citizenship: Coming Out 'Clean' Without Turning 'Green'?” Environmental Politics 19(4): 518-537.

Medistiara, Yulida. 2018. "Isi Perut Bangkai Paus Penuh Sampah, Ini Kata WWF." Detik.com. Retrieved July 20, 2019 (https://news.detik. com/berita/4309160/isi-perut-bangkai-pauspenuh-sampah-ini-kata-wwf-indonesia)
Melo-Escrihela, Carme. 2008. "Promoting Ecological Citizenship: Rights, Duties and Political Agency." ACME: An International E-Journal for Critical Geographies 7 (2): 113-134.

Nugroho, Dedi Ari. 2017. Penguatan Ecological Citizenship melalui Penerapan Pendidikan Pancasila dan Kewarganegaraan Berbasis Masyarakat. Prosiding Konferensi Nasional Kewarganegaraan III (pp. 18-25). Yogyakarta: Universitas Ahmad Dahlan.

Prasetiyo, Wibowo H., and Dasim Budimansyah. 2016. "Warga Negara dan Ekologi: Studi Kasus Pengembangan Warga Negara Peduli Lingkungan dalam Komunitas Bandung Berkebun." Jurnal Pendidikan Humaniora 4(4):177-186

Putnam, Robert D. 1992. Making Democracy Work: Civic Tradition in Modern Italy. NewJersey: Priceton University Press.

Putra, Pandu Faningsyah. 2016. "Pembentukan Karakter Peduli Lingkungan dalam Organisasi GreenPeace Regional Yogyakarta." Jurnal Kebijakan Pendidikan 5(2):135-148.

Sanneh, Edward Saja. 2018. "Sustainable Development." Pp. 55-63 in Systems Thinking for Sustainable Development. Switzerland: Springer

Sustainable Europe Research Institute, GLOBAL 2000 \& Friends of the Earth Europe. 2009. "Overconsumption? Our use of the world's natural resources". Retrieved July 24, 2019 (https://cdn.friendsoftheearth.uk/sites/defaultfiles/downloads/overconsumption.pdf)

Swandana, Irwan. 2017. "Peran Komunitas Pemuda Bidang Lingkungan dalam Mewujudkan Ketahanan Lingkungan (Studi pada Komunitas Jogja Berkebun Yogykarta)". Tesis. Yogyakarta: Universitas Gadjah Mada.

Tindangen, Leonard S. 2017. "Peran Generasi Muda dalam Meningkatkan Kesadaran Hukum Masyarakat tentang Pengelolaan Limbah Domestik di Kota Manado." Lex Et Societatis 5 (8): 13-18.

Tjokrowinoto, Moeljarto. 2012. Pembangunan 
Dilema dan Tantangan. Yogyakarta: Pustaka Pelajar

Travaline, Katharine and Christian Hunold. 2010. "Urban Agriculture and Ecological Citizenship in Philadelphia." Local Environment: The International Journal of Justice and Sustain ability 15(6):581-590.

Undang-Undang Republik Indonesia Nomor 32 Tahun 2009 Tentang Perlindungan dan Pengelolaan Lingkungan Hidup.

Welle, Deutsche. 2019. "Greta Thunberg, Remaja 16 Tahun yang Dinominasikan Raih Nobel Perdamaian." Detik.com. Retrieved Juli 15, 2019 (https://news.detik.com/dw/d-4472813/ greta-thunberg-remaja-16-tahun-yang-dinominasikan-raih-nobel-perdamaian)

Widjajanti, Darwina. 2014. Pengantar Pemahaman Pendidikan Konsumsi Berkelanjutan di Indonesia (Rekomendasi Nasional dan Panduan Bagi Pengambil Kebijakan dan Pendidik). Jakarta: Yayasan Pembangunan Berkelanjutan dalam Kemitraan dengan United Nations of Environment Programme (UNEP)

Winter, Gerd. 2013. "Ecological Pproportionality." Pp. 111-129 in Rule of Law for Nature. New York: Cambridge University Press.

Wolf, Johanna, Katrina Brown and Declan Conway. 2009. "Ecological Citizenship and Climate Change: Perceptions and Practice." Environmental Politics 18(4):503-521.

World Commission on Environment and Development. 1987. Our Common Future. Oxford: Oxford University Press

WWF. 2012. Living Planet Report 2012. Gland: World Wide Fund for Nature 